\title{
The Impact of Visitor Satisfaction Mediation from the Relationship between Marketing Information Systems, Tourist Destinations and Service Quality towards Returning Interest in Malang Topeng Village Tourism Destinations
}

Stella Alvianna, Fitria Earlike Anwar Sani*, Estikowati, Alwin Lasarudin, Syarif Hidayatullah University of Merdeka Malang, East Java, Indonesia

Article History

Received: 23.11 .2020

Accepted: 07.12.2020

Published: 13.12.2020

Journal homepage:

https://www.easpublisher.com

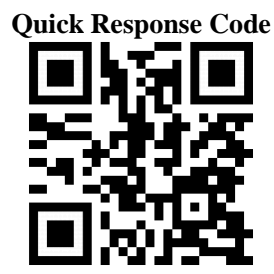

Abstract: Returning Interest is the result of visitor satisfaction. The purpose of this study is to examine and analyze the impact of visitor satisfaction as a mediating variable of the relationship between marketing information systems, tourist destinations, and service quality on interest in returning to visit. This research is an explanatory research, with the location of this research being conducted in the Tourism Destination of Mask Village, Malang City, and East Java. The population in this study is all people /communities who have visited the tourist destinations of Malang Topeng Village. With a sample size of 180 respondents. The data analysis technique uses descriptive statistical analysis, path analysis and hypothesis testing. From the results of the analysis and discussion, the results of the Marketing Information System and service quality do not affect the interest in returning to visit, while tourist destinations have an effect on the interest in returning to visit. However, the marketing information system, tourist destinations, and service quality affect the interest in returning to visit through the satisfaction of visiting tourists to the tourist destinations of Kampung Mask Malang, so it can be said that the satisfaction of visiting actually acts as mediation in this study.

Keywords: Marketing Information Systems, Tourist Destinations, Service Quality, Visiting Satisfaction, Returning Interest.

Copyright (C) 2020 The Author(s): This is an open-access article distributed under the terms of the Creative Commons Attribution 4.0 International License (CC BY-NC 4.0) which permits unrestricted use, distribution, and reproduction in any medium for non-commercial use provided the original author and source are credited.

\section{INTRODUCTION}

Indonesia is an archipelago in Asia, Southeast Asia, which is located between the Asian Continent and the Australian Continent KBBI [1]. Indonesian tourism is a potential national economic driver to spur economic development in the future according to [2]. Pariwista has the meaning that tourism is a variety of tourist activities and is supported by various facilities and services provided by the community, businessmen, government and local governments [3]. Indonesia has various areas with potential for tourism attraction that can attract tourists, one of which is Malang City.

Topeng Tourism Village is located in Baran Hamlet, Tlogowaru, Kedungkandang District, and Malang City. This Topeng Tourism Village is located in a fairly highland area and there are many trees and other ornamental plants that make the atmosphere in this mask tourism village feel cool and beautiful. In the Mask Tourism Village area, there are large masks of Panji Asmoro Bangun and Dewi Sekartaji. Both are wise kings and queens in the folklore of Malang. The two masks have a height of $6 \times 7$ meters; therefore these two masks are used as mascots in the Mask Village Tour.
In terms of theory, Tlogowaru Mask Village Tourism has fulfilled 4 (four) main components, namely the existence of tourist attractions, in a tourist destination. For accessibilities to the Tlogowaru Topeng Village Tour, it is paved and there are directional signs installed at road intersections leading to Kampung Topeng Tourism. For amenities, there are toilet facilities and a prayer room. For Ancillary, there are still no additional tourist facilities such as a tourist information center. In 2019, information obtained from the 2020 social service; there were very few visitors who came either on Sundays or weekends and weekdays. The formulation of the problem in this study is whether the marketing information system, tourist destinations and service quality have a partial and simultaneous effect on visiting satisfaction in Malang Topeng Village? Do the Marketing Information System, tourist destinations and service quality affect simultaneously and partially on the interest in returning to Malang Topeng Village? Does the Marketing Information System indirectly influence the interest in returning through visitor satisfaction in Malang Topeng Village? Do tourist destinations have an indirect effect on the interest in returning to visit through visitor satisfaction in Malang Topeng Village? Does service quality have an indirect effect on interest in returning to 
visit through visitor satisfaction in Malang Topeng Village?

\section{Methodology}

This research focuses on the study of tourism management, especially related to marketing information systems, tourist destinations, service quality, and customer satisfaction as well as the decision to return to visit. This research is an explanatory research; the location of this research is conducted in the tourist destination of Topeng Village, Malang City, East Java. The population in this study was all places of all people/communities who had visited Malang Topeng Village Tourism Destination. As for the research sample because the population is unknown, the researcher uses Prawira's opinion [4] to recommend that the minimum sample size is 5-10 times the number of question items in the questionnaire. As for the number of question items in this study were 18, so the maximum sample size of this study was $10 \times 18$ $=180$. The data analysis technique used descriptive statistical analysis, path analysis, classical asumsu test and hypothesis testing.

\section{Operational Definition Variable}

\begin{tabular}{|c|c|c|c|}
\hline No. & Research Variables & Operational Definition & Indicator \\
\hline 1 & $\begin{array}{l}\text { Marketing information } \\
\text { system }\end{array}$ & $\begin{array}{l}\text { An information system consisting of several } \\
\text { subsystems, such as the marketing research } \\
\text { subsystem and the transaction processing } \\
\text { subsystem }\end{array}$ & $\begin{array}{l}\text { Place Subsystem (X1) } \\
\text { Product Subsystem (X2) } \\
\text { Promotion Subsystem } \\
\text { (X3) } \\
\text { Price Subsystem (X4) }\end{array}$ \\
\hline 2 & Tourist Destination & $\begin{array}{l}\text { Is a potential or main attraction to encourage } \\
\text { tourists to travel }\end{array}$ & $\begin{array}{l}\text { Attraction } \\
\text { Accessibility } \\
\text { Amenity } \\
\text { Ancillary Service }\end{array}$ \\
\hline 3 & Service Quality & $\begin{array}{l}\text { The overall characteristics and characteristics of a } \\
\text { product or service in terms of its ability to meet } \\
\text { predetermined needs }\end{array}$ & $\begin{array}{l}\text { Reliability } \\
\text { Responsive } \\
\text { Assurance } \\
\text { Emphaty }\end{array}$ \\
\hline 4 & Satisfaction & $\begin{array}{l}\text { satisfaction is the feeling of pleasure or } \\
\text { disappointment of visitors that arise after } \\
\text { comparing the manager's performance with visitor } \\
\text { expectations }\end{array}$ & $\begin{array}{l}\text { 1. tourists are satisfied } \\
\text { with the existing facilities } \\
\text { and services } \\
2 . \text { Have a positive } \\
\text { impression after visiting } \\
\text { tours } \\
\text { 3. get good service when } \\
\text { visiting }\end{array}$ \\
\hline 5 & Interest in Revisiting & $\begin{array}{l}\text { the decision to visit again is an encouragement or } \\
\text { an interest from the tourists themselves to visit } \\
\text { again in the future }\end{array}$ & $\begin{array}{l}\text { 1. want to tell others about } \\
\text { the tour } \\
2 \text {. Want to recommend to } \\
\text { other people for traveling } \\
3 \text {. There is a desire to visit } \\
\text { again in the future }\end{array}$ \\
\hline
\end{tabular}

\section{ReSUltS AND DiscusSiON}

A total of 180 respondents filled out this research questionnaire online. The results of the hypothesis analysis of each path obtained from the results of the path analysis using SPSS software are as follows: 


\section{Demographic Statistics}

Table-1: Demographic Profile

\begin{tabular}{|c|c|c|c|}
\hline Item & Optional & Frequency & Percentag \\
\hline \multirow[b]{2}{*}{ Gender } & Male & 97 & 54 \\
\hline & Female & 83 & 46 \\
\hline \multirow{5}{*}{ Works } & Government Employees & 45 & 25 \\
\hline & Private Employees & 42 & 23 \\
\hline & Entepreneur & 38 & 21 \\
\hline & Student & 36 & 20 \\
\hline & More & 19 & 11 \\
\hline \multirow{4}{*}{ Income } & 0-Rp. 500,000 & 35 & 19 \\
\hline & Rp 500,000-Rp 1.000.000 & 43 & 24 \\
\hline & $\operatorname{Rp} 1.000 .000-\operatorname{Rp} 2.000 .000$ & 40 & 22 \\
\hline & $>\operatorname{Rp} 2.000 .000$ & 62 & 34 \\
\hline \multirow{4}{*}{$\begin{array}{c}\text { Lama } \\
\text { Berkunjung }\end{array}$} & 0-2 Times & 15 & 8 \\
\hline & 2-4 Times & 25 & 14 \\
\hline & 4-6 Times & 65 & 36 \\
\hline & $>6$ Times & 75 & 42 \\
\hline
\end{tabular}

Regression Analysis Model 1

Equation Model 1

$\mathrm{Z}=\mathrm{PZX} 1+\mathrm{PZX} 2+\mathrm{PZX} 3+\mathrm{e}$

Table 1: Results of Model I Regression Analysis Path Test

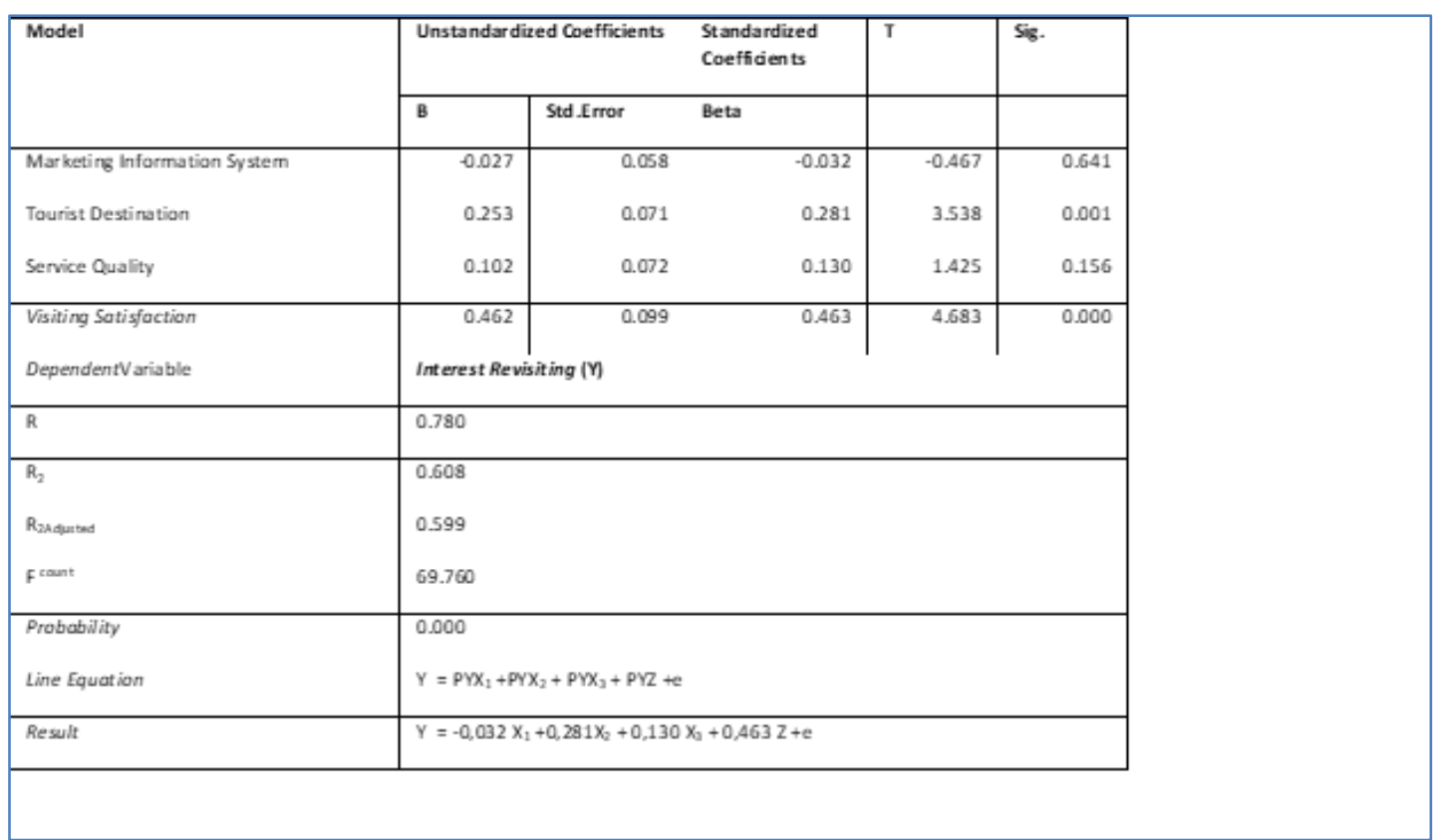

Source: Primary data, processed (2020)

In Table 1 , it can be seen that the regression model model I where the significant value of the Marketing Information System variable $(\mathrm{X} 1=0,000)$, Tourist Destinations $(\mathrm{X} 2=0,000)$, Service Quality (X3 $=0,000)$ means that the variables $\mathrm{X} 1, \mathrm{X} 2, \mathrm{X} 3$ have a significant effect because of the sig value. Smaller than 0.05 , but the value of $\mathrm{R} 2$ or $\mathrm{R}$ Square in the Model Summary table is 0.777 , this shows that the contribution or contribution of the influence of $\mathrm{X} 1 \mathrm{X} 2 \mathrm{X} 3$ on $\mathrm{Z}$ is $77.7 \%$, while the rest is 22.3 . \% is the contribution of other variables not included in this study. Meanwhile, the value of $\mathrm{e} 1=\sqrt{ }(1-0.777)=\sqrt{ }(0.223)=0.472$.

To find out whether the regression model above has a joint or simultaneous effect, the $\mathrm{F}$ test is needed. The $\mathrm{F}$ test shows that the results of the regression model I obtained F count 209,849 with a significant value of 0,000 , this means $0,000<0.05$, this means X1 X2 X3 simultaneously affects Z. 


\begin{tabular}{|c|c|c|c|c|c|}
\hline \multirow[t]{2}{*}{ Model } & \multicolumn{2}{|c|}{ Unstandardized Coefficients } & \multirow{2}{*}{$\begin{array}{l}\text { Standardized Coefficients } \\
\text { Beta }\end{array}$} & \multirow[t]{2}{*}{$T$} & \multirow[t]{2}{*}{ Sig. } \\
\hline & B & Std.Error & & & \\
\hline Sistem Informasi Pemasaran & -0.027 & 0.058 & -0.032 & -0.467 & 0.641 \\
\hline Destinasi Wisata & 0.253 & 0.071 & 0.281 & 3.538 & 0.001 \\
\hline Kualitas pelayanan & 0.102 & 0.072 & 0.130 & 1.425 & 0.156 \\
\hline Kepuasan Berkunjung & 0.462 & 0.099 & 0.463 & 4.683 & 0.000 \\
\hline DependentVariabel & \multicolumn{5}{|c|}{ Minat Berkunjung kembali (Y) } \\
\hline$R$ & \multicolumn{5}{|l|}{0.780} \\
\hline$R_{2}$ & \multicolumn{5}{|l|}{0.608} \\
\hline$R_{2 \text { adiusted }}$ & \multicolumn{5}{|l|}{0.599} \\
\hline F hitung & \multicolumn{5}{|l|}{69.760} \\
\hline Probability & \multicolumn{5}{|l|}{0.000} \\
\hline Line Equation & \multicolumn{5}{|c|}{$Y=P Y X_{1}+P Y X_{2}+P Y X_{3}+P Y Z+e$} \\
\hline Result & \multicolumn{5}{|c|}{$Y=-0,032 X_{1}+0,281 X_{2}+0,130 X_{3}+0,463 Z+e$} \\
\hline
\end{tabular}

Regression Analysis Model 2

Model equation $2 \square \mathrm{Y}=\mathrm{PYX} 1+\mathrm{PYX} 2+\mathrm{PYX} 3+\mathrm{PYZ}+\mathrm{e}$

Table 2: Results of the Regression Analysis Path Test Model 2

Source: Primary data, processed (2020)

Referring to the regression output of Model II, it can be seen that the significant value of the Tourism Destination variable $(\mathrm{X} 2)=0.001$, and Visiting Satisfaction $(\mathrm{Z})=0.000$ is smaller than 0.05 . This concludes that the Tourism Destination variable (X1) and the Visit Satisfaction variable $(\mathrm{Z})$ have a significant effect on Return Visit Interest (Y), for the Tourism Destination variable, and the Visit Satisfaction variable. This concludes that Visiting Satisfaction (Z) has a significant effect on Returning Interest (Y), then the Marketing Information System variable (X1) and the Service Quality variable (X3) have a probability sig value of 0.641 and 0.156 which is greater than 0.05., which means the Marketing Information System (X1) and the Service Quality variable (X3) have no effect on the Returning Interest variable (Y). The value of $\mathrm{R} 2$ or $\mathrm{R}$ Square in the Model Summary table is 0,608 , this indicates that the contribution or contribution of influence, $\mathrm{X} 1, \mathrm{X} 2, \mathrm{X} 3$ and $\mathrm{Z}$ to $\mathrm{Y}$ is $60.8 \%$, while the rest is $39.2 \%$. is the contribution of other variables that are not included in this study. Meanwhile the value of e1 $=\sqrt{ }(1-0.358)=\sqrt{ }(0.392)=0.626$

To find out whether the model II regression above has a joint or simultaneous effect, an F test is needed. The $F$ test shows that the results of the regression model II result in the F count of 69,760 with a significant value of 0,000 , this means $0,000<0.05$, this means $\mathrm{X} 1, \mathrm{X} 2, \mathrm{X} 3$ and $\mathrm{Z}$ together have a significant effect on $\mathrm{Y}$

\section{Hypothesis testing}

Table-3: Calculation of direct, indirect and total effects

\begin{tabular}{|l|r|r|l|l|l|}
\hline Hypothesis & $\begin{array}{l}\text { Direct } \\
\text { Effect }\end{array}$ & Probability & $\begin{array}{l}\text { Indirect } \\
\text { Effect }\end{array}$ & Total Effect & Inforrmation \\
\hline $\mathrm{X} 1 \rightarrow \mathrm{Z}$ & 0,555 & 0,000 & & & Significant \\
\hline $\mathrm{X} 2 \rightarrow \mathrm{Z}$ & 0.695 & 0,000 & & & Significant \\
\hline $\mathrm{X} 3 \rightarrow \mathrm{Z}$ & 0.859 & 0,000 & & & Significant \\
\hline $\mathrm{X} 1 \rightarrow \mathrm{Y}$ & -0.032 & 0.641 & & & No Significant \\
\hline $\mathrm{X} 2 \rightarrow \mathrm{Y}$ & 0.281 & 0.001 & & & Significant \\
\hline $\mathrm{X} 3 \rightarrow \mathrm{Y}$ & 0.130 & 0.156 & & & No Significant \\
\hline $\mathrm{Z} \rightarrow \mathrm{Y}$ & 0.463 & 0.000 & & & Significant \\
\hline $\mathrm{X} 1 \rightarrow \mathrm{Z} \rightarrow \mathrm{Y}$ & & & $\begin{array}{l}0,555 \times 0,463 \\
=0,257\end{array}$ & $\begin{array}{l}-0,032+0,257 \\
=0,225\end{array}$ & Significant \\
\hline $\mathrm{X} 2 \rightarrow \mathrm{Z} \rightarrow \mathrm{Y}$ & & & $\begin{array}{l}0,695 \times 0,463 \\
=0,321\end{array}$ & $\begin{array}{l}0,281+0,321 \\
=0,602\end{array}$ & Significant \\
\hline $\mathrm{X} 3 \rightarrow \mathrm{Z} \rightarrow \mathrm{Y}$ & & & $\begin{array}{l}0,859 \times 0,463 \\
=0,398\end{array}$ & $\begin{array}{l}0,130+0,398 \\
=0,528\end{array}$ & Significant \\
\hline
\end{tabular}

Source: Primary data, processed (2020) 
Based on the test results in table 3, it is known that the coefficient of the Marketing Information System, Tourism Destinations, and Service Quality on Returning Interest, there are only two independent variables which are not significant, namely the influence of the Marketing Information System variable on Returning Interest with the probability of 0.641 and the variable. Service Quality for Returning Interest with the probability amount is 0.156 . Meanwhile, the indirect effect of the variable marketing information system, tourist destinations, and service quality on revisiting interest through visitor satisfaction gets significant results.

\section{DISCUSSION}

\section{Effect of Marketing Information Systems on Visiting Satisfaction}

From the test using the SPSS program the results of the first regression model (I), it is known that the effect of the Marketing Information System on Visiting Satisfaction, the $\mathrm{X}_{1}$ variable (Marketing Information System) obtained the value of $\mathrm{t}$ count $=$ 9.033 with a significance level of 0.000 , which means using alpha (significant limit) $5 \%(0.05)$ can be interpreted that the first hypothesis which says that there is an influence between the Marketing Information System on Visiting Satisfaction can be accepted or tested statistically. This article is in line with research conducted by [10] where the results of this study found that the information system is an activity that describes a plan for a system developed to solve a problem.

\section{The Effect of Tourist Destinations on Visit Satisfaction}

From testing using the SPSS program, the results of the first regression model (I), it is known that the influence of tourist destinations on visiting satisfaction, variable $\mathrm{X}_{2}$ (tourist destinations), obtained a value of $t$ count $=13,068$ with a significance level of 0.000 , which means using alpha (significant limit) $5 \%$ $(0.05)$ can be interpreted that the influence of tourist destinations on visiting satisfaction can be accepted or tested statistically. This article is in line with the research conducted by [9] where the results of this study found that the tourism components which in this case consist of attractions, amenities, accessibility, ancillaries on Gemah Tulungagung beach have a significant effect on visitor satisfaction.

\section{Effect of Service Quality on Visit Satisfaction}

From the test using the SPSS program, the results of the first regression model (I), it is known that the effect of Service Quality on Visiting Satisfaction, variable $\mathrm{X}_{3}$ (Service Quality) obtained a value of $\mathrm{t}$ count $=22.663$ with a significance level of 0.000 , meaning using alpha (significant limit) 5\% (0.05) can be interpreted that the influence of Service Quality on Visiting Satisfaction can be received or statistically tested. This article is in line with research conducted by
[8]. Where the results in this study found that service quality variables affect visitor satisfaction either directly or indirectly, this will have an impact on promotional variables and destination image.

\section{The Effect of Marketing Information Systems on Returning Interest}

From the test using the SPSS program, the results of the second regression model (II), it is known that the influence of tourist destinations on revisiting interest, variable $\mathrm{X}_{1}$ (Marketing Information System) obtained a value of $t$ count $=-0.467$ with a significance level of 0.641 , which means using alpha (significant limit) \% (0.05) means that the influence of the Marketing Information System on Returning Interest can be accepted or tested statistically. This article is not in line with the research conducted by [5]. Where the results of this study found that the Marketing Information System has a significant effect on visitor loyalty, in that visitor loyalty will also have an impact on the interest in returning to visit, whereas in this study marketing information system does not have a direct influence on Returning Interest.

\section{The Influence of Tourist Destinations on Returning Interest}

From the test using the SPSS program the results of the first regression model (I), it is known that the influence of tourist destinations on visiting satisfaction, variable $\mathrm{X}_{2}$ (tourist destinations), obtained a value of $t$ count $=3,358$ with a significance level of 0.001 , which means using alpha (significant limit) $5 \%$ (0.05) can be interpreted that the influence of tourist destinations on visiting satisfaction can be accepted or tested statistically. This article is in line with research conducted by [7]. Where the results of this study found that attractions, amenities, accessibility, and ancillary have a positive and significant effect on visitor satisfaction, each element of tourist destinations can provide positive tourist perceptions so that they can have an impact. Positive for interest in returning.

\section{The Effect of Service Quality on Returning Interest}

From testing using the SPSS program the results of the second regression model (II), it is known that the effect of Service Quality on Returning Interest, the X3 variable (Service Quality) obtained a value of $t$ count $=1.425$ with a significance level of 0.156 , meaning that using alpha (significant limit) $5 \%(0.05)$ can be interpreted that the influence of Service Quality on Return Visit Interest can be accepted or statistically tested. This article is not in line with the research conducted by [6] Where the results in this study indicate that promotion does not affect the interest in visiting, but if promotion and service quality together have an influence on interest in returning, whereas in this study the quality of service those in the mask village do not have an influence on the Interest of Visiting Again. 


\section{The Effect of Visiting Satisfaction on Returning Interest}

From the test using the SPSS program the results of the second regression model (II), it is known that the effect of Visiting Satisfaction on Returning Interest, variable $\mathrm{Z}$ (Visiting Satisfaction) obtained a value of $t$ count $=4,683$ with a significance level of 0.000 means using alpha (significant limit) $5 \%(0.05)$ means that there is an influence between Visiting Satisfaction and Returning Interest can be accepted or tested statistically. This article is in line with research conducted by (Mulyana and Ayuni)where the results in this study show that tourist satisfaction at Bogor Waterfall Tourism Park has a significant effect on the intention to return, the same thing happens in the Malang mask village, tourists who visit are satisfied so that the interest in visiting Returning tourists are increasing.

\section{The Effect of Marketing Information Systems on Returning Interest through Visit Satisfaction}

Visiting Satisfaction as a moderating variable between the Marketing Information System variable and Returning Interest has an indirect effect value greater than the direct effect value $(0.257>-0.032)$ of the marketing information system variable on the interest in returning to visit. With the conclusion that the better the marketing information system in Malang Topeng Village will have an impact on the satisfaction of visiting tourists and can be followed by the interest in returning the tourists to Malang Topeng Village. The results of this study are in line with research conducted by (Hidayatullah, Patalo, et al.) That in this study the marketing information system has an influence on competitive advantage through customer loyalty, whereas in this study the marketing information system does not directly affect the interest in returning to visit. With these results it can be said that the variable of visiting satisfaction is really a mediator in this study

\section{The Influence of Travel Destinations on Returning Interest through Visit Satisfaction}

Visiting satisfaction as a moderating variable between tourist destinations and interest in visiting Return can be seen from the magnitude of the indirect effect with a direct effect with a value of $(0.321>0.281)$ that exists from tourist destinations to visitor satisfaction on interest in visiting Back of tourists. So it can be concluded that this research is in line with the research conducted by (Alvianna et al.)In this study, the results show that the components of tourist destinations (attractions, ancillary, amenities, and accessibility) have a positive and significant effect on customer satisfaction. This can also show the perception that tourists get a positive impact on tourist attractions. Likewise with this research, it can be shown that tourist destinations have a positive and significant effect on the interest in returning to visit both directly and indirectly, which in this case tourist destinations also affect the interest in returning to visit through visiting satisfaction.

\section{The Effect of Service Quality on Returning Interest} through Visit Satisfaction

Customer satisfaction as a moderating variable that links service quality with interest in visiting again is seen from the value of the indirect effect $(0.398)$ with the direct effect (0.130). Judging from the indirect effect which has a value greater than the direct effect, it means that there is a significant effect. It can be concluded that improved service quality can increase visiting satisfaction which in turn will automatically increase interest in returning to visit. The results of this research also support the research conducted by [2]. The results of this study show that service quality has a positive and significant effect on intention to return to visit, both partially and simultaneously, both of which have positive and significant results. Likewise with this study, that the quality of service affects the interest in returning to visit through visiting satisfaction, but when the quality of service and interest in visiting return alone, there is no effect, so it can be seen that visiting satisfaction really becomes mediation in this study. Without visiting satisfaction, the quality of service does not have any effect.

\section{CONCLUSION}

From the analysis and discussion, it is found that the marketing information system, tourist destinations, and service quality have a significant effect on visitor satisfaction. Marketing information systems and service quality have no effect on interest in returning to visit, but tourist destinations have a significant effect on interest in visiting back, and visiting satisfaction has a significant effect on interest in visiting back. The Marketing Information System has a significant effect on Returning Interest through visiting satisfaction. Tourist destinations have a significant effect on interest in returning through visiting satisfaction. Service quality has a significant effect on interest in returning to visit through visit satisfaction.

In this study, it was found that the marketing information system did not have a direct influence on the interest in tourist visits, but when there was visit satisfaction as mediation, the results were that the marketing information system had an effect on the interest in returning to visit through visiting satisfaction. This means that if tourists make a return visit not only because the marketing information system is good and useful, but also because tourists are satisfied when visiting Malang Topeng Village tourist destinations.

While tourist destinations have an influence on the interest in visiting Return either by using visiting satisfaction as a mediation, or directly influencing the interest in visiting Return, or it can be interpreted that without visiting satisfaction, tourists also have a high interest in visiting Return too, this is because tourist destinations are located in Kampung Topeng Malang has a tourist attraction in the form of uniqueness and 
beauty, which is also supported by tourism facilities and adequate accessibility.

Service quality has an influence on the interest in visiting again through visiting satisfaction, but the quality of service does not have a direct influence on the interest in visiting back, so it can be interpreted that tourists who make repeat visits to the mask village tourist destinations are tourists who are satisfied during their visit to In Kampung Topeng Malang, the satisfaction felt is mainly satisfied with the quality of services provided by the management of Malang Mask Village.

\section{REFERENCE}

1. Jerniati, I. (2019). Kosakata Serapan Bahasa Jepang dalam KBBI: Analisis Struktur dan Makna. Ranah: Jurnal Kajian Bahasa, 8(1).

2. Putra, I. G. N., Sudiarta, I. N., \& Mananda, I. G. S. (2016). Pengaruh Kualitas Pelayanan Dan Kepuasan Terhadap Niat Berkunjung Kembali Wisatawan Mancanegara Ke Daya Tarik Wisata Alas Pala Sangeh. Jurnal IPTA ISSN, 2338, 8633.

3. Rotberg, R. I. (2009). Governance and leadership in Africa: measures, methods and results. Journal of International Affairs, 62(2), 113-126.

4. Fahmi, F. Z., Prawira, M. I., Hudalah, D., \& Firman, T. (2016). Leadership and collaborative planning: The case of Surakarta,
Indonesia. Planning Theory, 15(3), 294-315.

5. Hidayatullah, S., Patalo, R. G., Firdianjah, A., \& Waris, A. (2019, September). Pengaruh sistem informasi pemasaran, kualitas pelayanan dan loyalitas terhadap keunggulan bersaing jatim park group. In Seminar Nasional Sistem Informasi (SENASIF), 3(1): 1652-1660.

6. Octaviani, D. (2020). "Pengaruh promosi dan kualitas pelayanan terhadap minat kunjung kembali wisatawan di kabupaten kubu kalimantan barat (studi kasus pada wisatawan di qubu resort)." $E$ journal equilibrium manajemen, 2020.

7. Alvianna, S. (2020). "Pengaruh Attraction, Accessibillity, Amenity, Ancillary Terhadap Kepuasan Generasi Millenial Berkunjung Ke Tempat Wisata." Jurnal Kepariwisataan: Destinasi, Hospitalitas Dan Perjalanan.

8. Sari, C. S., \& Maftukhah, I. (2017). Pengaruh Kualitas Layanan, Promosi dan Citra Destinasi terhadap Kepuasan melalui Keputusan Pengunjung. Management Analysis Journal, 6(3), 310-319.

9. Setyanto, I., \& Pangestuti, E. (2019). Pengaruh komponen destinasi wisata (4a) terhadap kepuasan pengunjung pantai gemah tulungagung. Jurnal Administrasi Bisnis, 72(1), 157-167.

Anton, H. (2014). Analisa Dan Perancangan Sistem Informasi Pemasaran Perumahan pada PT. Anugerah Bangun Cipta. 